\title{
(Non-)Kolbe Chemistry Going with the Flow: The Continuous Electrolysis of Biogenic Acids
}

Nils Kurig ${ }^{a}$, Jérôme Meyers ${ }^{a}$, F. Joschka Holzhäuser ${ }^{a}$, Stefan Palkovits ${ }^{a}$ and Regina Palkovits ${ }^{\text {* }}$

a Chair of Heterogeneous Catalysis and Chemical Technology Institute for Technical and Macromolecular Chemistry, RWTH Aachen University, Worringerweg 2, 52074 Aachen, Germany

* Correspondence to: palkovits@itmc.rwth-aachen.de

\section{Contents}

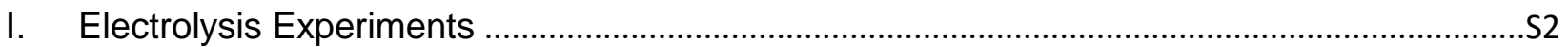

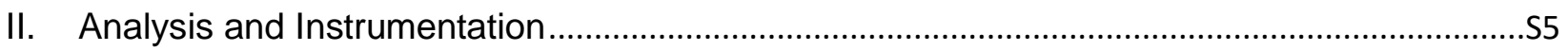

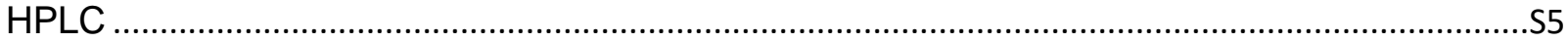

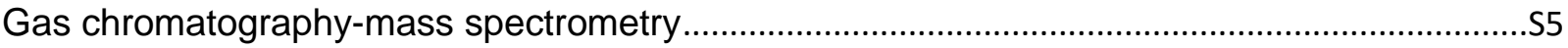

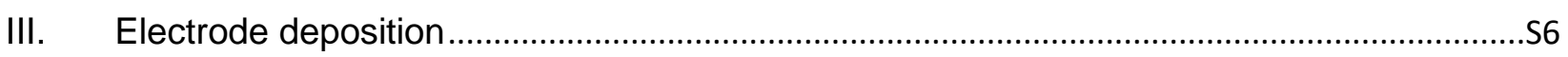

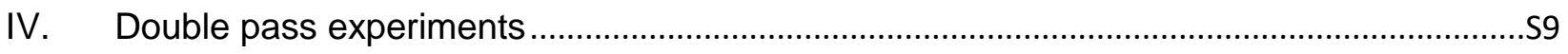

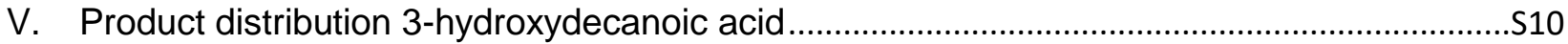

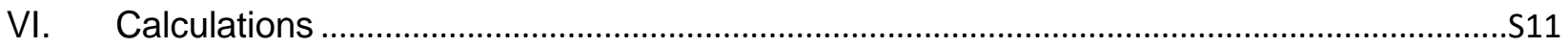

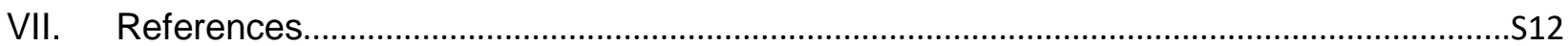

Pages S1 - S12

Figures $\mathrm{S} 1-\mathrm{S} 9$

Table S1

Scheme S1 


\section{Electrolysis Experiments}

Electrolysis experiments were conducted using three types of custom built reactors introduced in the following. Chemicals are listed in Table S1 and were used without further purification.

Table S1: Chemicals used for electrolysis experiments.

\begin{tabular}{lrr}
\hline Substance & Supplier & Purity \\
\hline \hline Decanoic acid & SAFC $^{\circledR}$ & $\geq 98 \%$ \\
Deuterated solvents & DEUTERO GmbH & $\geq 99 \%$ \\
Ethyl heptanoate & ALDRICH & $99 \%$ \\
Levulinic acid & ALDRICH $^{\circledR}$ & $98 \%$ \\
Methanol & LABSOLUTE $^{\circledR}$ & $\geq 99.8 \%$ \\
Potassium hydroxide & Honeywell Fluka $^{\text {TM }}$ & $\geq 85 \%$ \\
\hline
\end{tabular}

Batch experiments were conducted in $5 \mathrm{~mL}$ vials using 3D printed caps to mount electrode sheets of $5 \times 1 \mathrm{~cm}^{2}$. A Metrohm Autolab B.V. PGSTAT302N Potentiostat/Galvanostat was used in galvanostatic mode.

Flow experiments were conducted in semi-batch and single-pass setups using parallel plate electrolysis cells as well as 3D printed tubular cells. BASETech BT-305 Lab Mains Adapter was used for power supply and Fink Ritmo R05 for pumping. The different setups are shown in Figure S1 and Figure S2.

A custom-built single compartment parallel plate cell was employed. The electrode distance between working electrode and counter electrode was $10 \mathrm{~mm}$ in cell type $A$ and $C$, whereas the electrode surface area was $12.6 \mathrm{~cm}^{2}$ in Cell $A$ and $3 \mathrm{~cm}^{2}$ in Cell C. In contrast, Cell B is a 3D printed tubular reactor. The body of the electrolysis cell was initially constructed as a hollow tube but leaves the flexibility to optimize the flow pattern. Ports were drilled into the reinforced top sides providing access for standard HPLC fittings as well as for custom-built connectors for rod electrodes (roughly $6 \mathrm{~mm}$ diameter). The tubular cell provides $7 \mathrm{~cm}^{2}$ electrode surface at $14 \mathrm{~mm}$ distance and a volume of $26 \mathrm{~mL}$. In both cases, the tubing volume was roughly $3 \mathrm{~mL}$, including the $1.4 \mathrm{~mL}$ heat exchanger volume. 


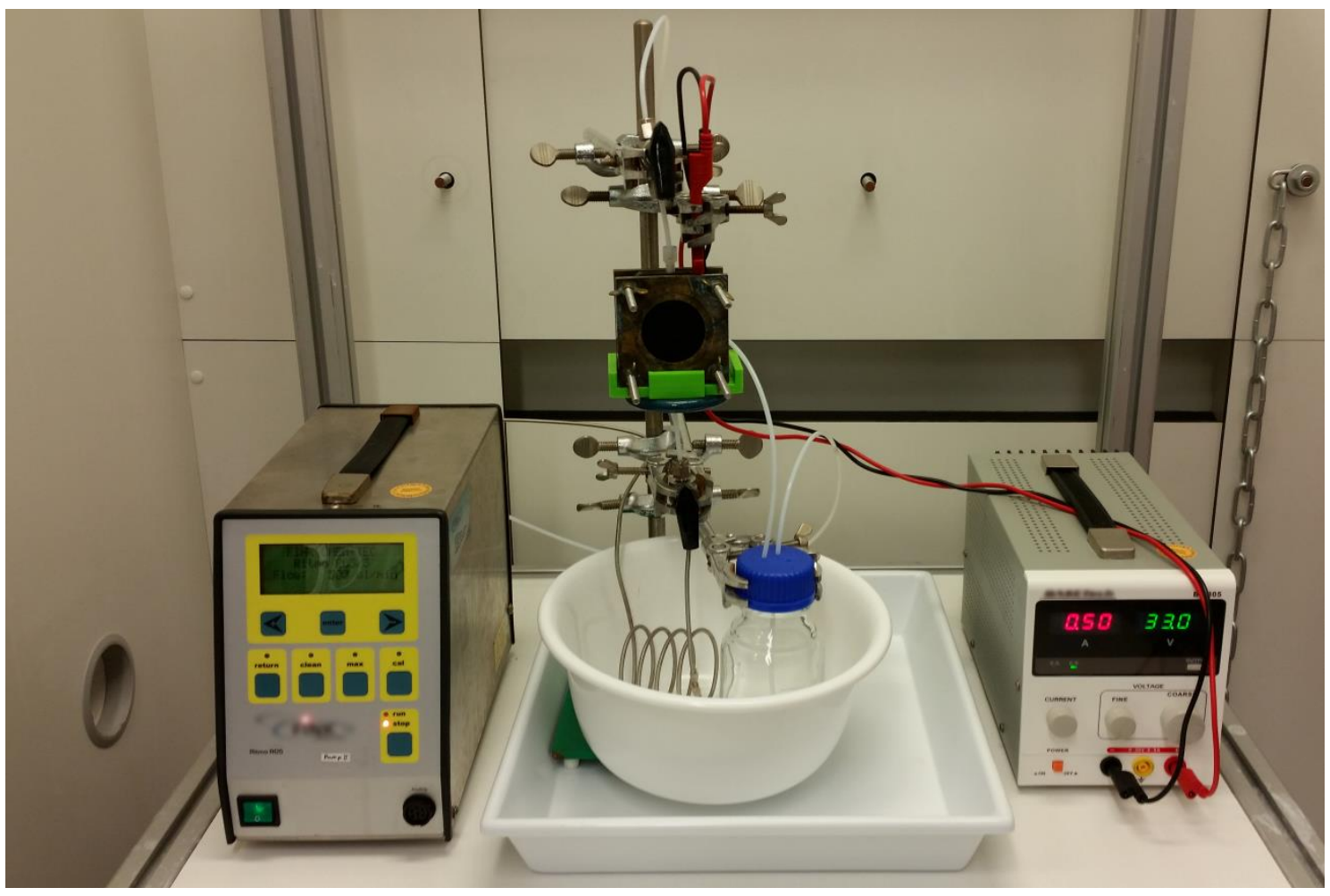

Figure S1: Setup for semi-batch experiments in conventional cell.

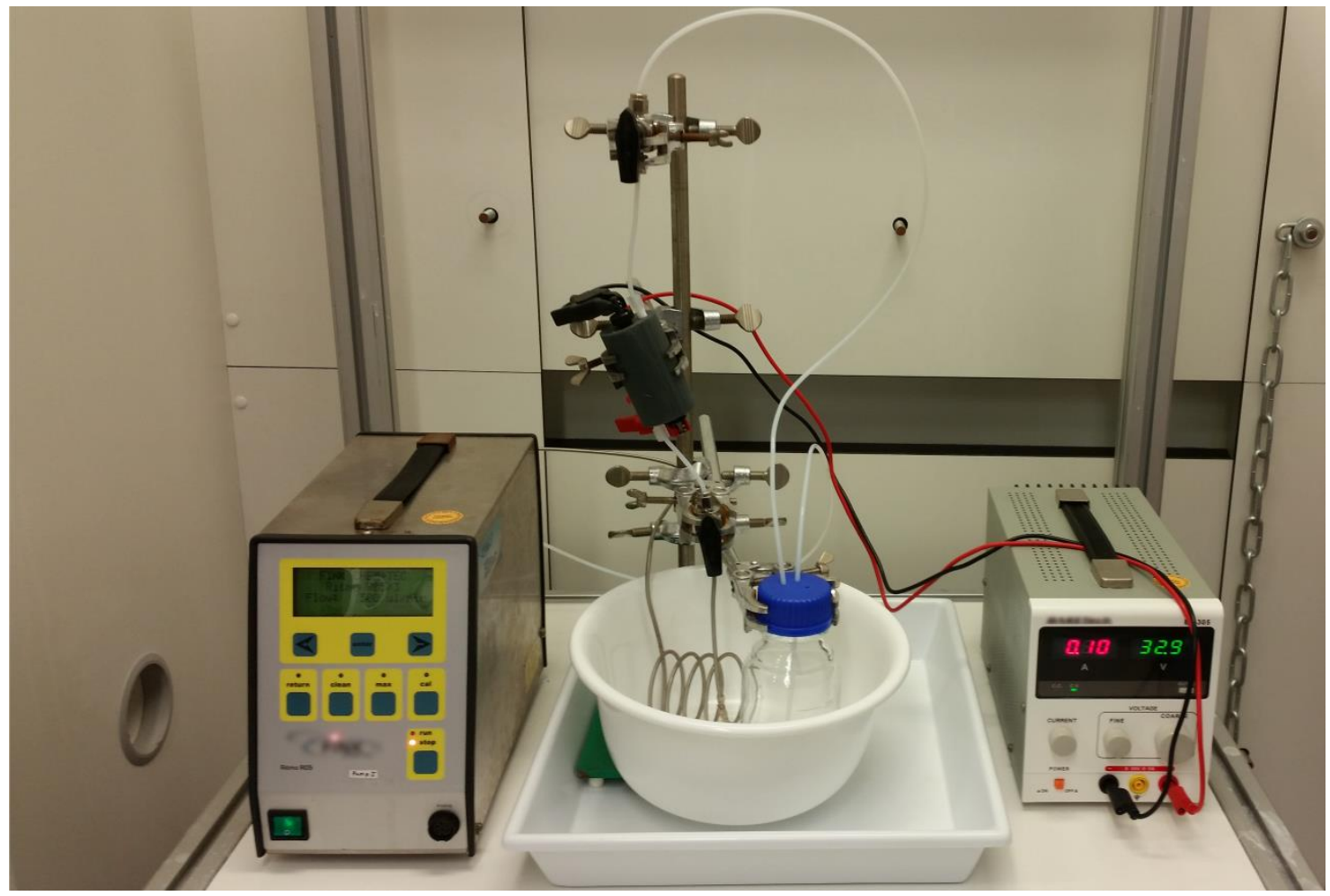

Figure S2: Setup for semi-batch experiments in 3D printed cell. 


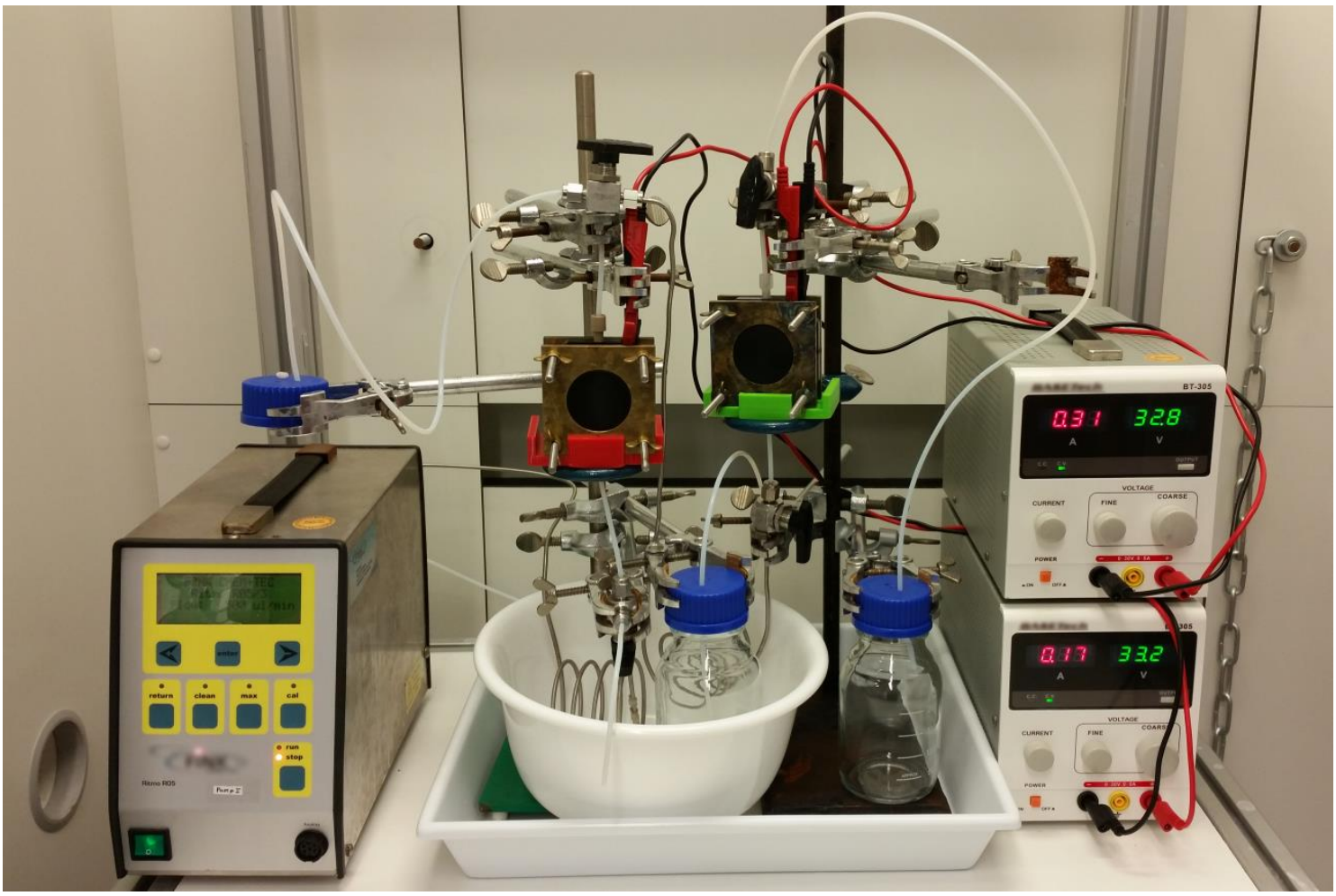

Figure S3: Double pass setup for continuous Kolbe electrolysis. 


\section{Analysis and Instrumentation}

\section{HPLC}

The aqueous phase was analyzed via high-performance liquid chromatography (Shimadzu Prominence LC-20 system) equipped with a RI detector and a Macherey Nagel-NucleodurC18 Gravity column. The samples were eluted at $40{ }^{\circ} \mathrm{C}$ with a $70: 30$ (vol.\%) mixture of acetonitrile and 0.2 wt.\% aqueous formic acid using a flow rate of $1.0 \mathrm{~mL} \mathrm{~min}{ }^{-1}$. After completion of each electrolysis experiment, the mixture was acidified and extracted with $1 \mathrm{~mL} \mathrm{H}_{2} \mathrm{O}$ and $2 \mathrm{~mL} n$ heptane. The products of the organic phase were quantified using a Thermo Scientific Chromatograph Trace GC Ultra equipped with a CP-WAX-52 $(60 \mathrm{~m})$ column. Every sample contained $15 \mathrm{mg}$ of ethyl heptanoate as internal standard and $1 \mathrm{~mL} n$-heptane as solvent. $\mathrm{N}_{2}$ was used as carrier gas with a constant flow rate of approximately $1.5 \mathrm{~mL} \mathrm{~min}^{-1}$ along with an inlet temperature of $250^{\circ} \mathrm{C}$ and a split flow of $50 \mathrm{~mL} \mathrm{~min}^{-1}$. A temperature program of $70^{\circ} \mathrm{C}$ $(5 \mathrm{~min})$ and $200^{\circ} \mathrm{C}(15 \mathrm{~min})$ with a heating ramp of $8^{\circ} \mathrm{C} \mathrm{min}-1$ was used for the analysis of $1 \mu \mathrm{L}$ of the sample.

\section{Gas chromatography-mass spectrometry}

Measurements were carried out on a Varian CP-3800 gas chromatograph equipped with a CPWAX-52 column $(60 \mathrm{~m} \times 250 \mu \mathrm{m} \times 0.25 \mu \mathrm{m})$ and a Varian 1200L Quadrupole MS/MS fitted with an electron ionization (EI) source. The volume of injected sample was $1 \mu \mathrm{L}$ (diluted in methanol 1:10) and the GC signal was recorded with a flame ionization detector (FID). The El voltage was set at $70 \mathrm{eV}$ with a transfer capillary temperature of $250{ }^{\circ} \mathrm{C}$ and an ion source temperature of $250^{\circ} \mathrm{C}$. 


\section{Electrode deposition}

Scheme S1. Oligomerization reaction of methyl vinyl ketone.<smiles>[R]CCC(C)=O</smiles>

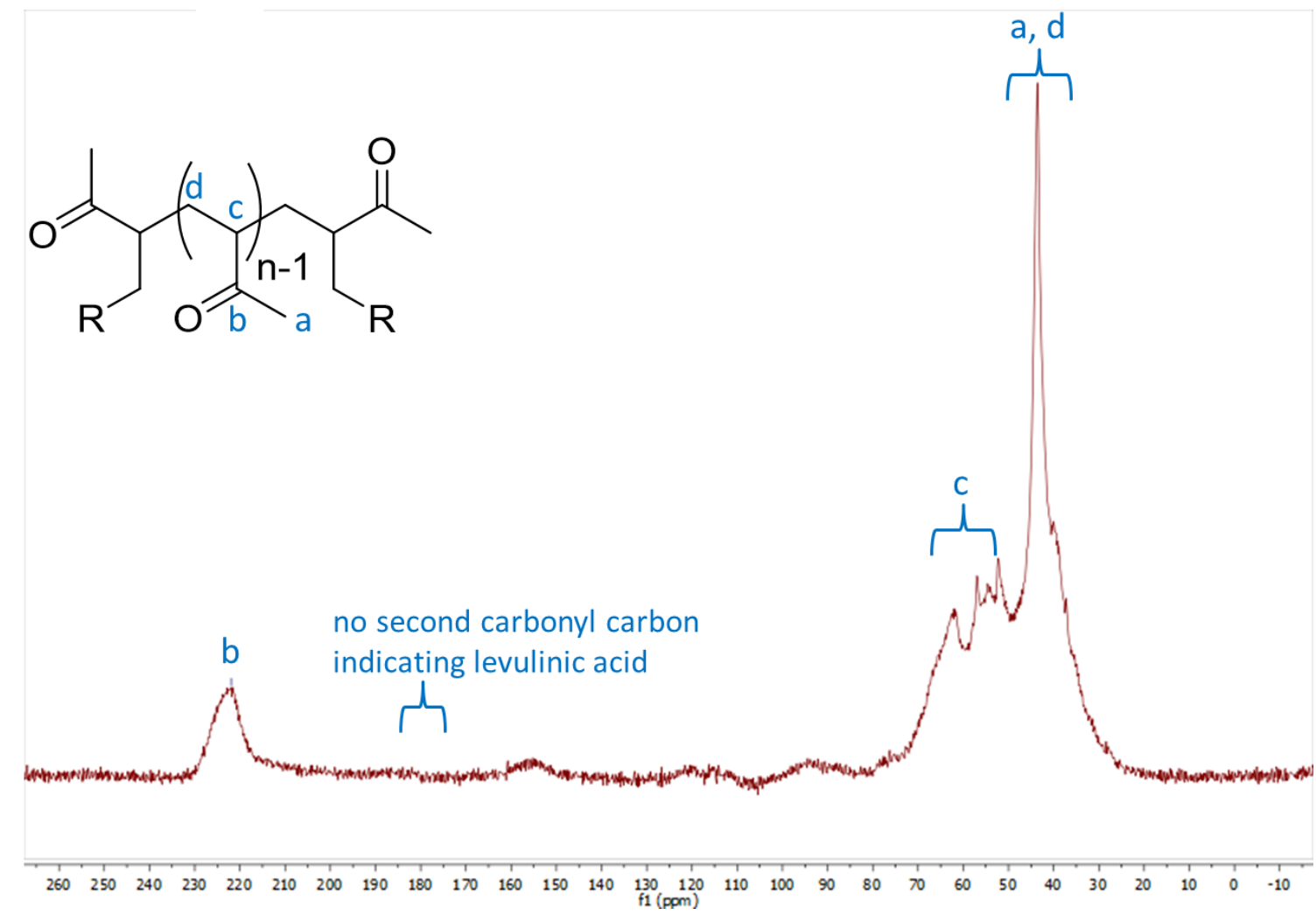

Figure S4: Solid state ${ }^{13} \mathrm{C}$ NMR of the electrode deposition. 


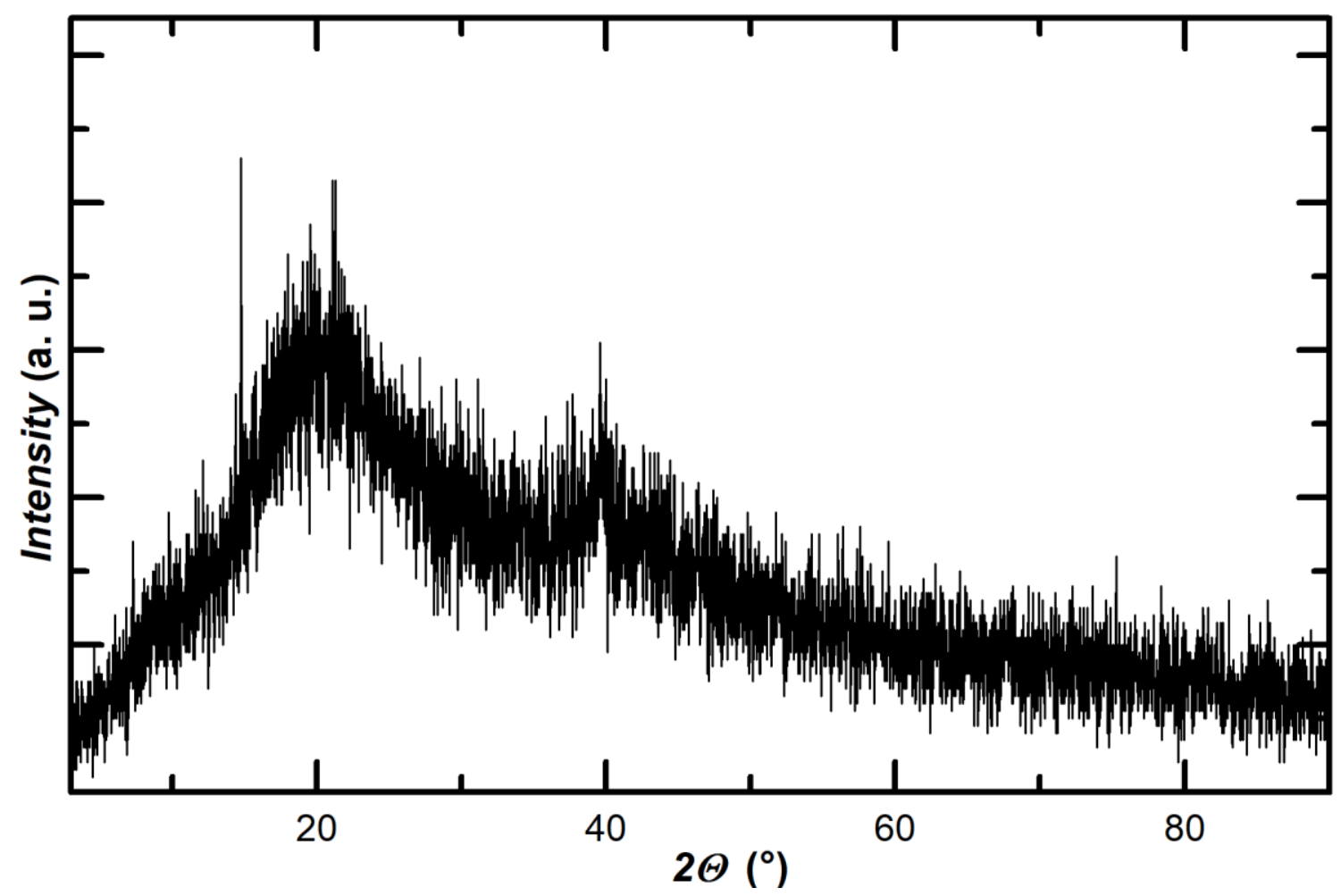

Figure S5: Powder diffractogram of the electrode deposition. The absence of peaks indicates an amorphous substance.

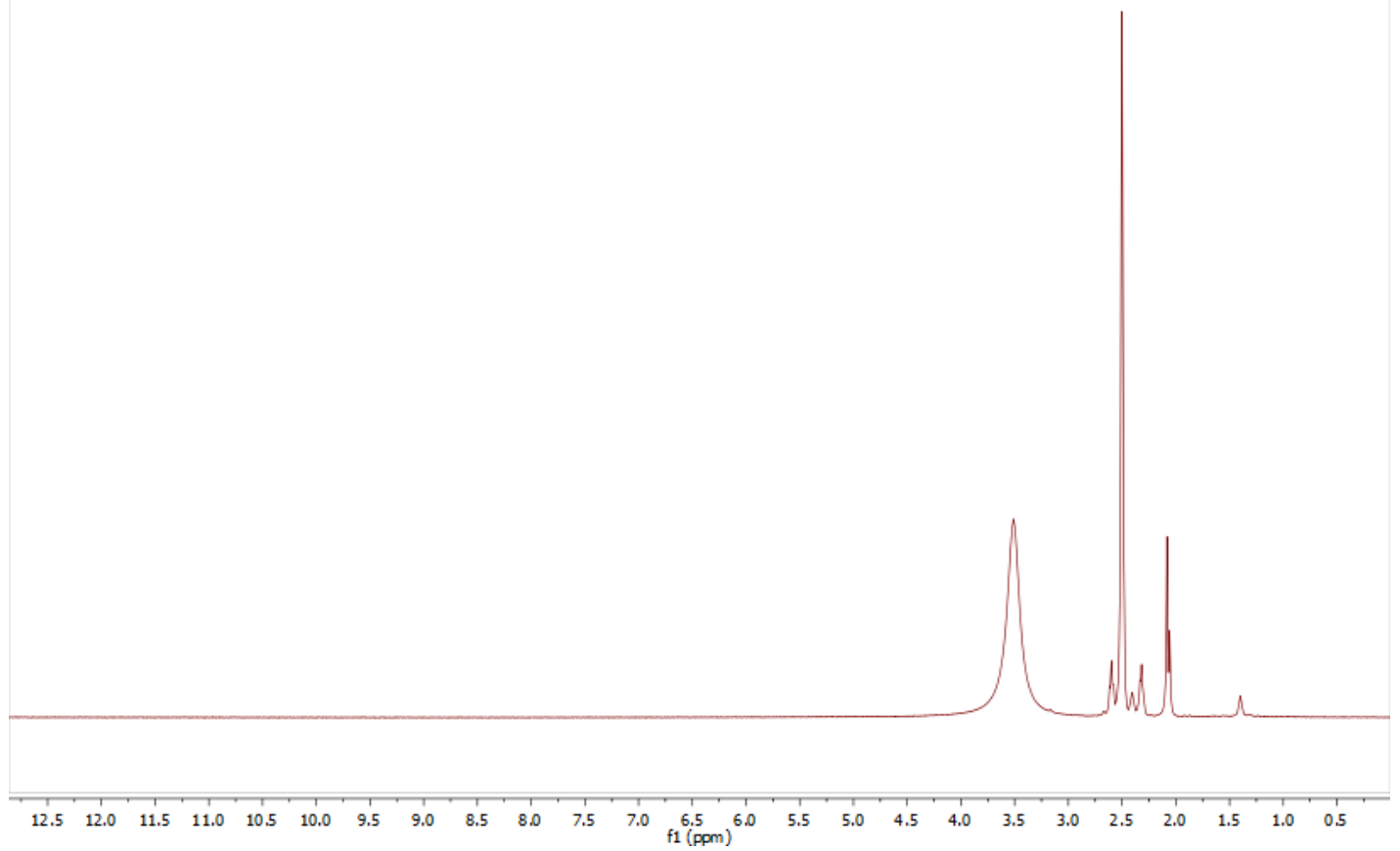

Figure S6: ${ }^{1} \mathrm{H}$ NMR of the electrode deposition measured in DMSO. 


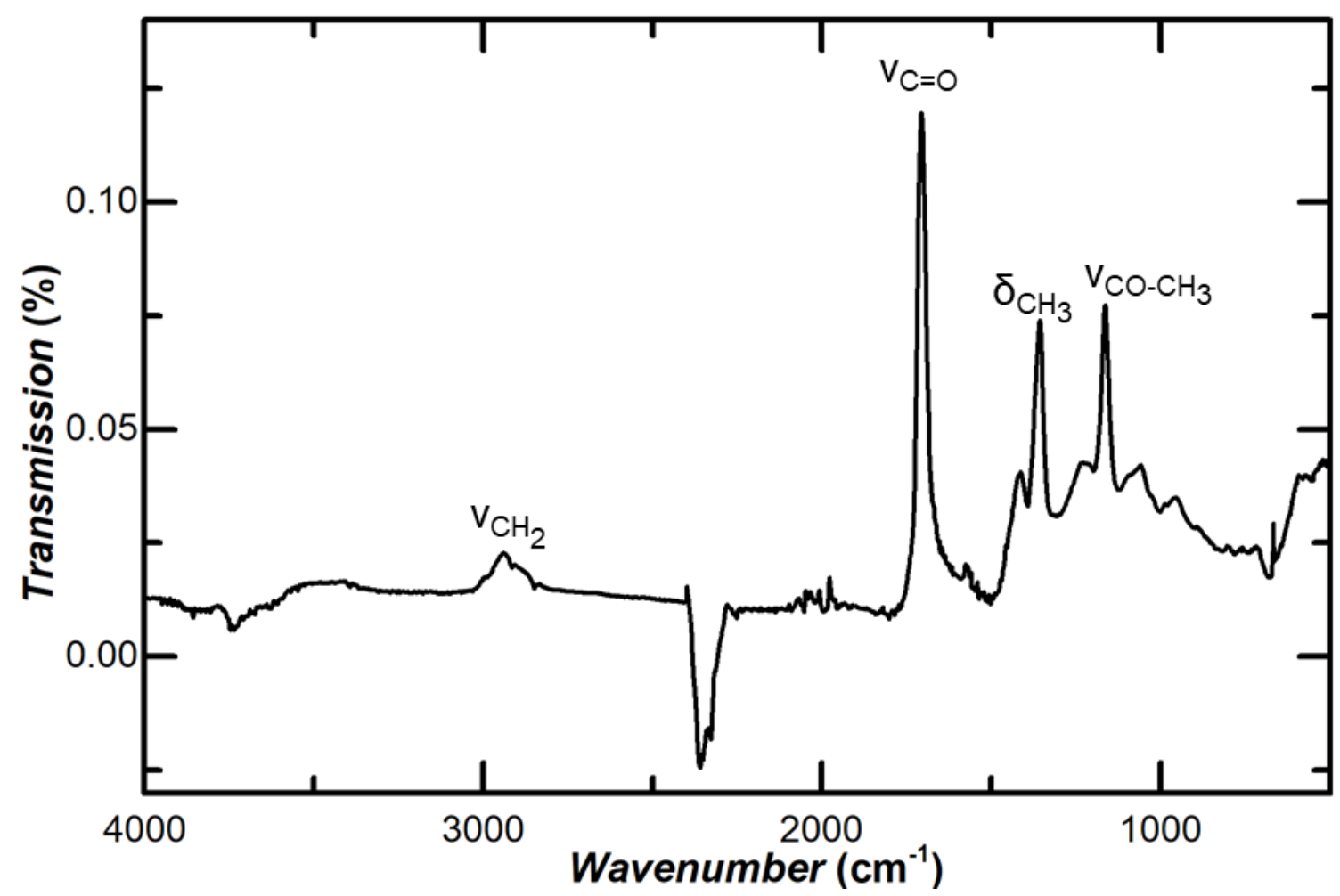

Figure S7: ATR-IR spectrum of the electrode deposition measured in transmittance. For comparison see reference by Grassie et al. ${ }^{1}$ 


\section{Double pass experiments}
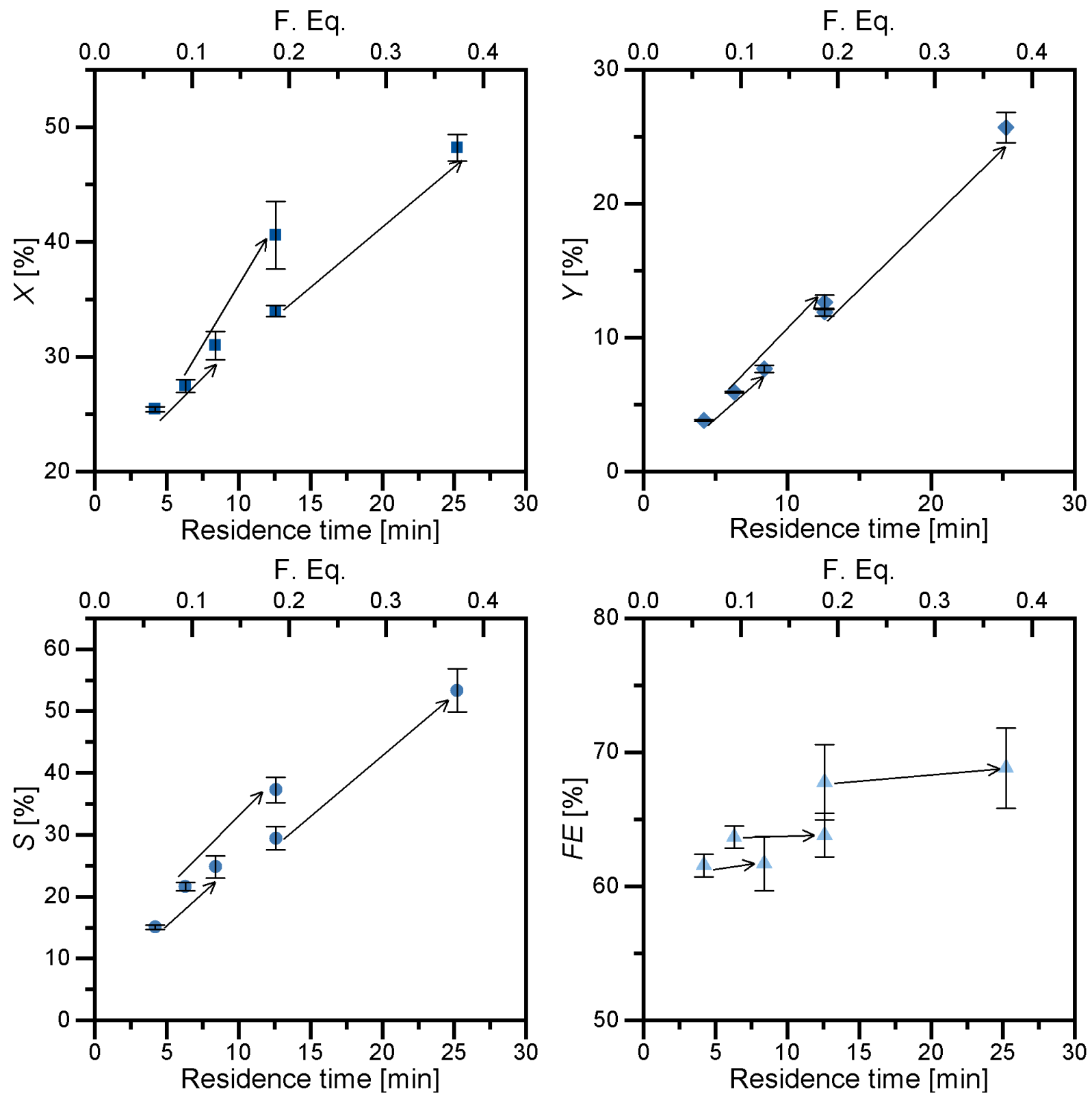

Figure S8: Conversion, yield, selectivity, and Faradaic efficiency measured for the Kolbe dimerization of levulinic acid in a double pass setup. $X=$ conversion, $Y=$ yield, $S=$ selectivity, $F E=$ faradaic efficiency. 


\section{Product distribution 3-hydroxydecanoic acid}

Product distribution

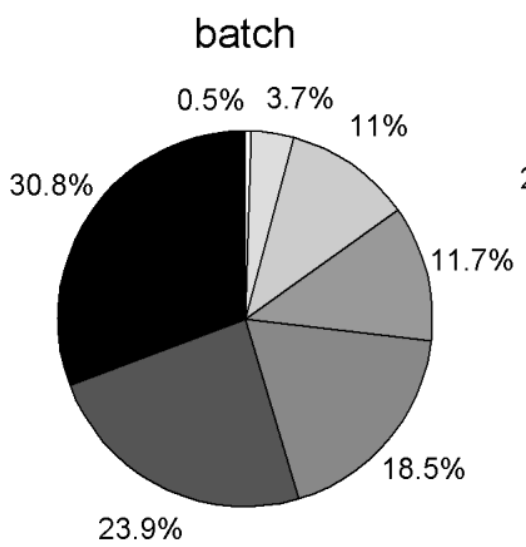

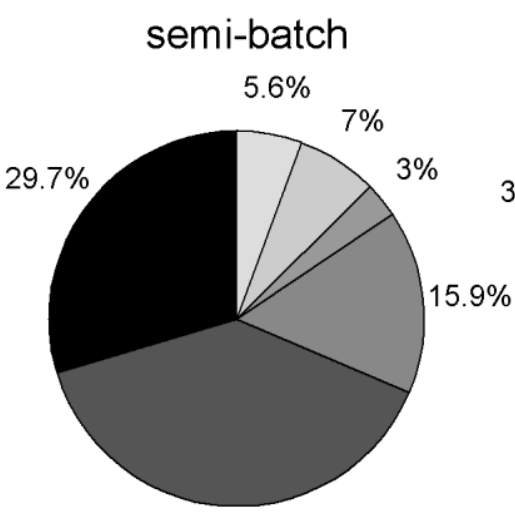

$38.9 \%$

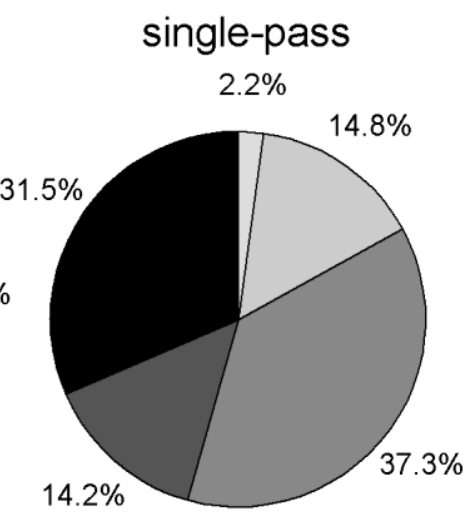

\section{1-Nonanol $\square$ Nonane $\square$ Methyl nonanoate} Nonanal 2-Nonanone

Figure S9: Product distribution of different Non-Kolbe experiments converting 3-hydroxydecanoic acid to a drop-in fuel mixture. Batch results are taken from reference by Meyers et al. ${ }^{2}$ 


\section{Calculations}

Calculation of time for bulk electrolysis:

$$
Q=I t \quad Q=n z F \quad t=\frac{n z F}{I}
$$

( $Q=$ charge in A s, $I=$ current in A, $t=$ time in $\mathrm{s}, n=$ amount of substrate in mol, $z=$ number of electrons transferred, $F=$ Faraday constant)

Consequently, the theoretical conversion can be calculated. A theoretical conversion of $100 \%$ is also called 1 Faraday equivalent:

$$
\frac{I t}{n z F}=X_{\text {theo. }} \text { (F.Eq.) }
$$

The faradaic efficiency $(F E)$ resembles an electrochemical selectivity and can be calculated as follows:

$$
F E=\frac{Y}{X_{\text {theo. }}}
$$

The hydrodynamic residence time ( $t$ in $\mathrm{s}$ ) is calculated from the reactor volume ( $V$ in $\mathrm{mL}$ ) and the liquid flow rate $\left(F\right.$ in $\left.\mathrm{mL} \mathrm{min}^{-1}\right)$ :

$$
\tau=\frac{V}{F}
$$




\section{References}

(1) Grassie, N.; Hay, J. N. The Thermal Degradation of Poly(Methyl Vinyl Ketone) and Its Copolymers with Acrylonitrile. Die Makromol. Chemie 1963, 64 (1), 82-94. https://doi.org/10.1002/macp.1963.020640107.

(2) Meyers, J.; Mensah, J. B.; Holzhäuser, F. J.; Omari, A.; Blesken, C. C.; Tiso, T.; Palkovits, S.; Blank, L. M.; Pischinger, S.; Palkovits, R. Electrochemical Conversion of a BioDerivable Hydroxy Acid to a Drop-in Oxygenate Diesel Fuel. Energy Environ. Sci. 2019, 12 (8), 2406-2411. https://doi.org/10.1039/C9EE01485C. 